\title{
A Proposed electronic Instructional Game TO IMPROVE DeCISION TAKING SKILL
}

\author{
By \\ M. E. El-Alami, \\ Head of Computer Teacher \\ Preparation Department \\ Faculty of Specific Education, \\ Mansoura University \\ A. E. Amin, \\ Computer Teacher \\ Preparation Department \\ Faculty of Specific Education, \\ Mansoura University \\ Omima Magdi El-Saadawi \\ M. Sc. Researcher
}

Research Gournal Specific Fducation

Faculty of Specific Fducation

gYansoura University

ISSUE NO. 42, APRIL. 2016

مجلة بعوث التربية النوعية - جامعة المنصورة

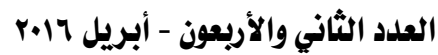


- A Proposed Electronic Instructional Game to Improve Decision Taking Skill 


\title{
A Proposed electronic Instructional Game
}

\section{TO IMPROVE DECISION TAKING SKILL}

\author{
M. E. El-Alami *
}

A. E. Amin ${ }^{* *}$

O. M. El-Saadawi ${ }^{* * * *}$

\section{Abstract}

Over the last years, game-based learning (GBL) has considered as one of the most promising technologies on learning and teaching practice in and out of formal educational environments. Game-based learning especially electronic instructional ones can be used to improve different skills of pupils. Reviews of relevant researches show that there is a shortage in Arabic electronic instructional game, so that a little Arabicgames are being applied in Arab World schools. The purpose of the current study is to propose an Arabic instructional design/development model, which can be used to create Arabic game-like learning environments. The study presents an application on the use of electronic instructional games in improving decision taking skill in English language curriculum for sixth grade pupils.

\section{Introduction:}

Rapid developments in information and communication technologies have affected all areas of life including education, and this has brought about changes in the structure and implementation of education and the roles of individuals in education. Many educational institutions have begun seeking new models to meet the needs of their students. One of the elements that provide such an environment is computers (Arslan, 2006). The spread of computer use in education and increase interest in educational computer games bring to the mind that using educational computer games in learning environment can be useful (Gungormus, 2007).

Head of Computer Teacher Preparation Department Faculty of Specific Education Mansoura University

** Computer Teacher Preparation Department Faculty of Specific Education Mansoura University

M. Sc. Researcher 
There are five key claims about the use of electronic educational games. The claims are (1) built on sound learning principles, (2) provide more engagement for the learner, (3) provide personalized learning opportunities, (4) teach $21^{\text {st }}$ century skills, and (5) provide an environment for authentic and relevant assessment. (McClarty et al., 2012).

Nowadays a lot of games are found on the Internet, but a little of them can be considered as educational games. Unfortunately there is a shortage of Arabic educational games for Arabic-speaking pupils. While there is vast number of studies and papers about the perception of students and their reactions, the question of how to incorporate games into learning environments stays unresolved(Pivec, 2006). The main contribution of this study reveals important information and illuminates the path that goes to the answer of the above-mentioned question.

Computer games are considered as powerful tools to learning and they have a potential for educational use.Games that improve working memory capacity, are important element in problem solving (Hawes et. al., 2013). Computer games and simulations have appeared on the scene of instructional design/development activities more than three decades ago (Gredler, 1996).Students of today are growing up with laptops, tablets, cell phones, and video calls. They expect to use this technology in their daily interactions (NCREL \&Metiri, 2003).

One area of significant promise in this regard is a movement toward the use of educational video games as learning tools in schools. In response to this movement, several commercial and custom made video games have been used in K-12 classrooms across the world to enhance students " learning experience (Wastiau, Kearney, \& Van den Berghe, 2009) The 2011 Horizon report suggests that augmented reality and game-based learning will gain widespread use in two to three years (Johnson, Smith, Willis, Levine, \& Haywood, 2011).

In 2005, the Federation of American Scientists, the Entertainment Software Association, and the National Science Foundation brought together nearly 100 experts to consider ways to develop next generation 
learning games. They found that many of the skills required for success in games such as thinking, planning, learning, and technical skills are also sought by employers (Federation of American Scientists, 2006). In Secretary of Education Arne Duncan's 2010 National Education Technology Plan, he calls for research in how "assessment technologies, such as simulations, collaborative environments, virtual worlds, games, and cognitive tutors, can be used to engage and motivate learners while assessing complex skills" (United States Department of Education, 2010, p. 15).

This study has a general aim to contribute to knowledge base in instructional design theory and to make a humble contribution to the organizational and somewhat social phenomenon of creating an Arabic game-like learning environment. More precisely, the purpose of the current study is to propose an Arabic instructional design/development model, which may be used in the creation of game-like learning environments.

\section{A Proposed Framework}

This section introduces a proposed instructional design/development model that can help and guide instructional designers and/or game designers for the efficient use of games and simulations in educational environments.

The proposed frameworkwill reflect the distinctive characteristics of an instructional design/development process for the creation of game-like learning environments. It will define the necessary and sufficient components of an appropriate instructional design/development model for the creation of game- like learning environments. Finally it will design the ways that these components come together to form a model.

The first module of designing the frameworkis to define the required Intended Learning Outputs (ILOs) and the main objective of the game and learning content of the course. This section is called the "Learning module". The second module is the "Instructional Design module". This module includes all the rules and steps required to make the game funny and achievingeducational targets. The last module is the "Evaluation module", which includes feedback of system. The proposed system frameworkis shown in figure 1. 


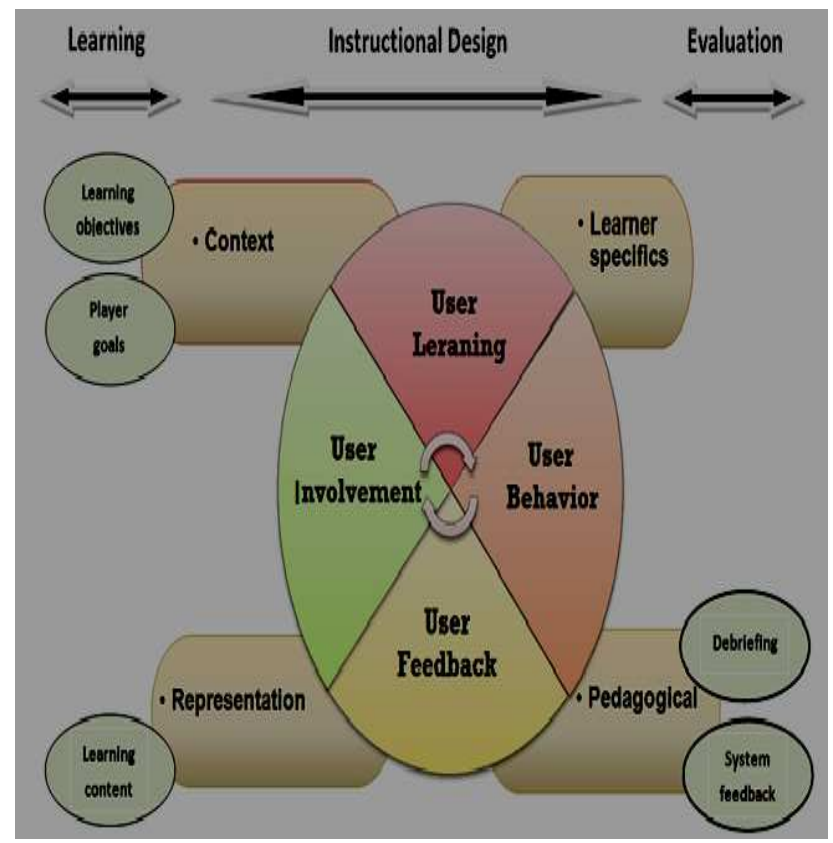

Fig.1:The Proposed Framework

\section{The Proposed Game}

The proposedframework is applied to design an electronic educational game used to improve decision taking skillfor the sixth primary pupils in Egypt. The game is based on the Egyptian Intended Learning Outputs (ILOs) for primary schools. The objective of the game is to develop the decision taking skill and improve the time of taking the right decisionin English language curriculumfor sixth grade pupils.

In this game we combine between achieving the ILOs for the sixth grade and the other objectives of the game. Five ILOs are targeted by the designed game. TheseILOs include:(1) increase the cognitive structure of English words, (2) be able to communicate in English simply, (3) develop reading and listening skills in English, (4) expand assented, so composed with different cultures, and (5) increase his / her experience in English and how is it different from an Arabic language. 


\subsection{Programming Language}

In this study, we useFlash's visual work and graphic design environment, and also its built-in programming language called Action Script. A programming language is a kind of language, similar to English, which humans can use to communicate with computers. The Action Script language is used for programming the proposed game. There are many reasons which make the Flash as one of the most powerful tools for game development. These reasons can be summarized as follow:

1. Web deployment: Since Flash files are designed to be viewed in Web pages, Flash is a good choice if you want your game to be available on the Internet.

2. Small file size: Flash makes use of vector graphics and compressed sound files, so a Flash game's final file size can be exponentially smaller than those of games developed on other platforms.

3. Plug-in penetration: The plug-in that's required for viewing Flash files in a Web page comes with all major browsers. More than 98 percent of people on the Internet worldwide can view Flash content.

4. Server-side integration: Flash games can talk to the server seamlessly. Using Flash's built-in features, you can communicate with server-side applications that make chats, multiplayer games, and high score lists possible.

5. File sharing between programmer and graphic artists/designers: With Flash, programmers and graphic artists can collaborate using the same files. This is rare in game development.

6. Ease of use: Perhaps one of the most attractive reasons for choosing Flash is that you can learn the program and start creating games in a very short time. With other languages, it could take years.

\subsection{Structure of the game}

The first section of the game is the "Learning module".In this module we determine the game goals and (ILOs) of the game. The player 
goal is to catch the fish which bearing the word that he/she listen to it on time. Learning content is English course of sixth grade.

The second module is the "Instructional Design module", which is divided into: Context, Learner Specifics, Representation, and Pedagogical sections. In the designed game the context is written inArabic language because it will be simpler for Arab (Egyptian) pupils to understand the game rule and objective in their mother tongue. The game rules allow one player only to play it. Regarding learner specifics: the feature of the game depends on solvable problems in ascending levels. The measure of the player progresses in achieving the goals (win conditions) of each level is identified by $60 \%$ of the score in the level. The levels difficulties increase by increasing the game speed. In representation phasewe made action-domain link by make the story of the game consists of catching fish, so that the learners can easily understand how to apply knowledge to the real world.We control the player's possibilities for active and direct manipulation of specific aspects of the game by using the mouse to choosethe right word.Regarding pedagogical we make the level of difficulty of the game gradually increases by increasing the difficulty of words, and increasing the speed and words of similar pronunciation. The player's achievement is recorded and the screen displays a message "you have successfully passed the level". The game gives the player a feedback on the outcomes of his actions.

The player's score can be displayed either on the screen or in a printable report by clicking the "print report" button. An instructions button containing all the required information is provided. In the proposed game the player does not have any effects on the real world. The only effect is thepossibility of losing the game score.

The last module is the "Evaluation module" which is divided into: Debriefing and System feedback sections. Concerning of debriefing; the players can be evaluated as individual players or they can compete as a group under the supervision of a teacher. The teacher can print report about every player. Concerning the system feedback; the achievement, progressand 
score of each player are recorded and displayed within the game. Every player can obtain a feedback on the outcomes of his actions.

\subsection{Game playing description}

The first screen of the game is a "welcome screen" which contains five buttons as depicted in Figure 2. The first one is the "Start game" button; the second one is the "Levels" button where you can choose one of the eight ascending levels. The third button is the "Print report" button from which the teacher can know the progress of any player (pupil). The forth button is the "Instructions" button from which the players can understand how to play the game. Finally, the fifth is buttonis the "Exit" button for ending the game. Figures 3-7 show screenshots of the resultant screens after clicking each buttons are shown in

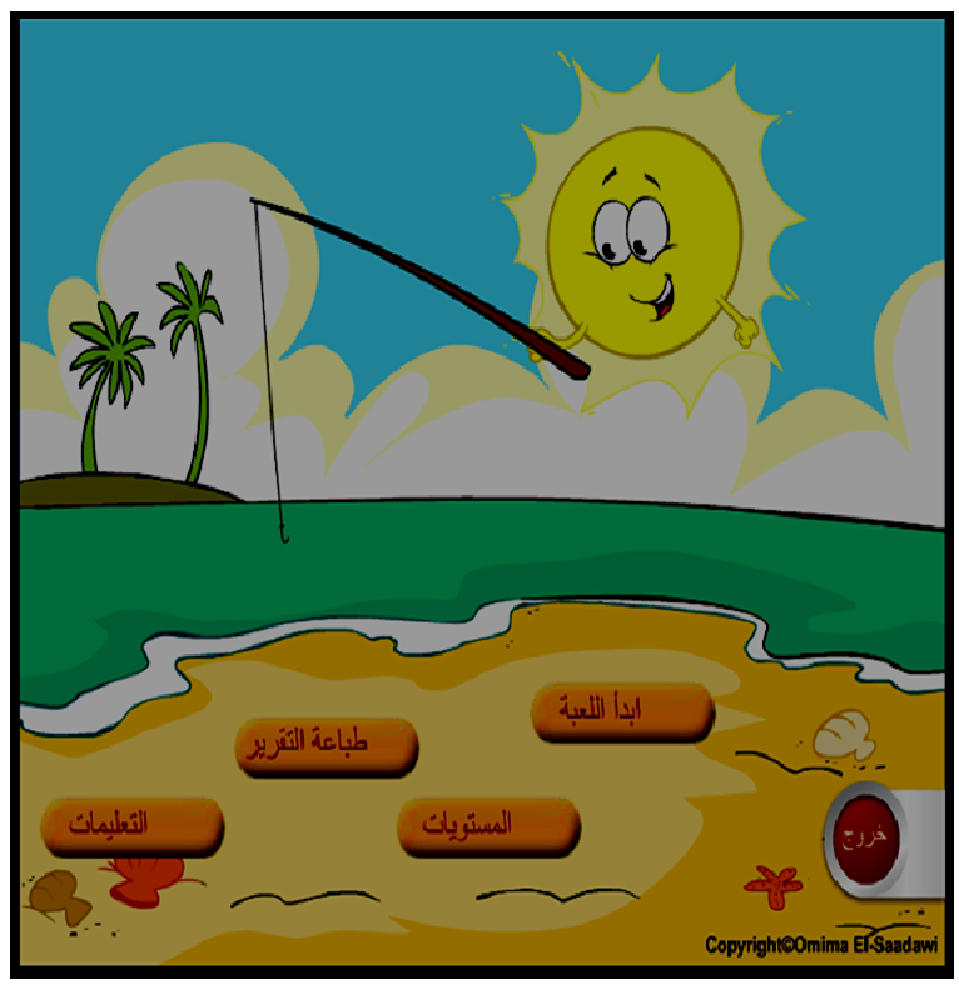

Fig.2: Welcome Screen 
- A Proposed Electronic Instructional Game to Improve Decision Taking Skill

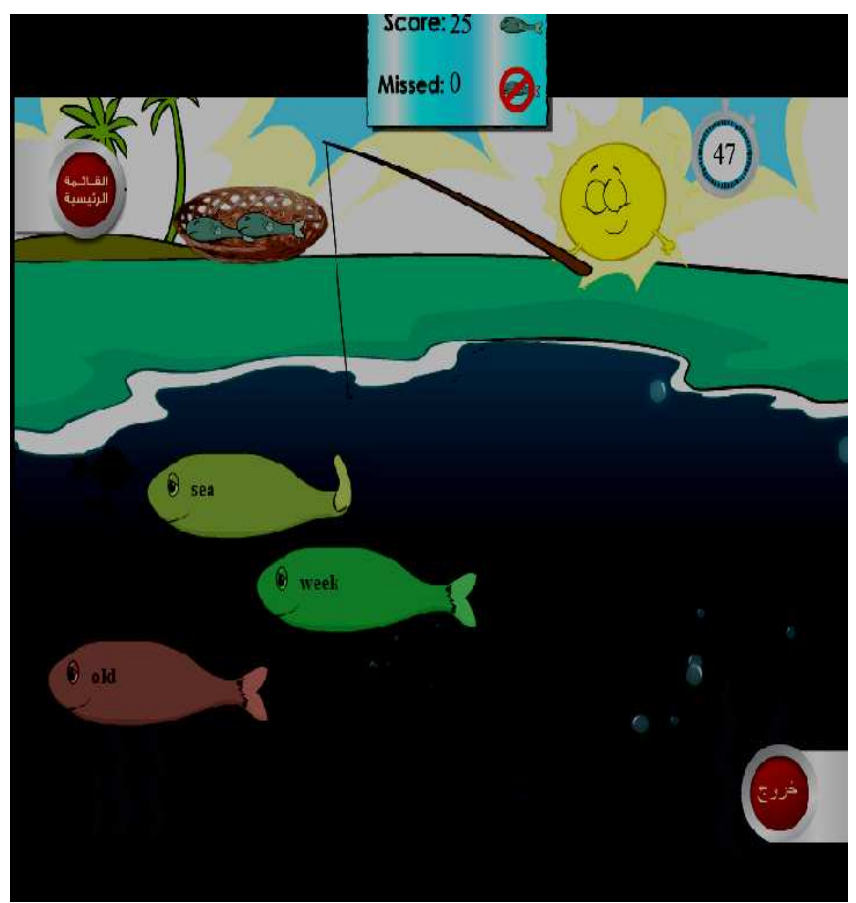

Fig. 3: Start Game Button Screenshot

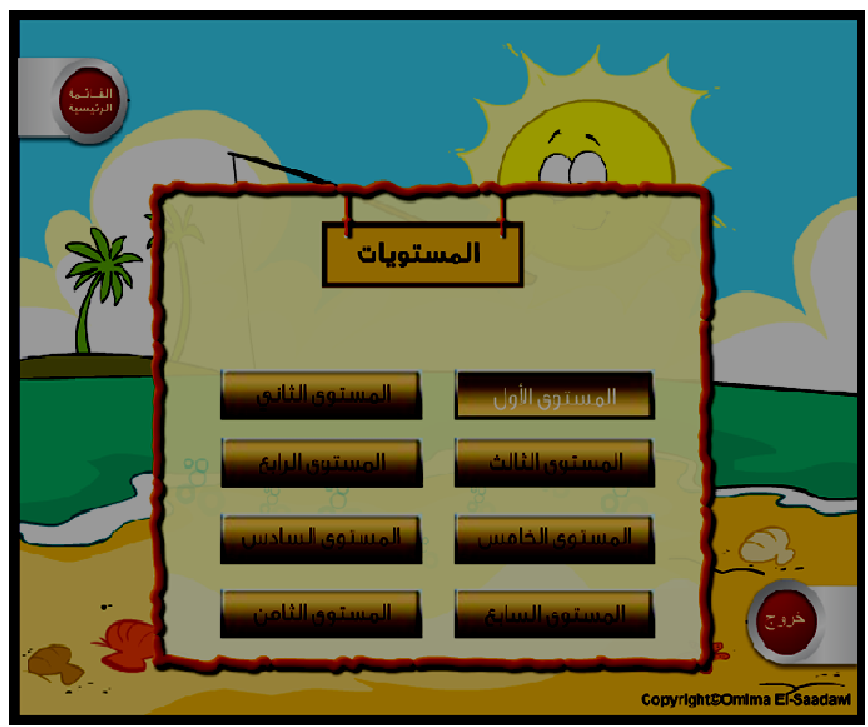

Fig. 4: Levels ButtonScreenshot 


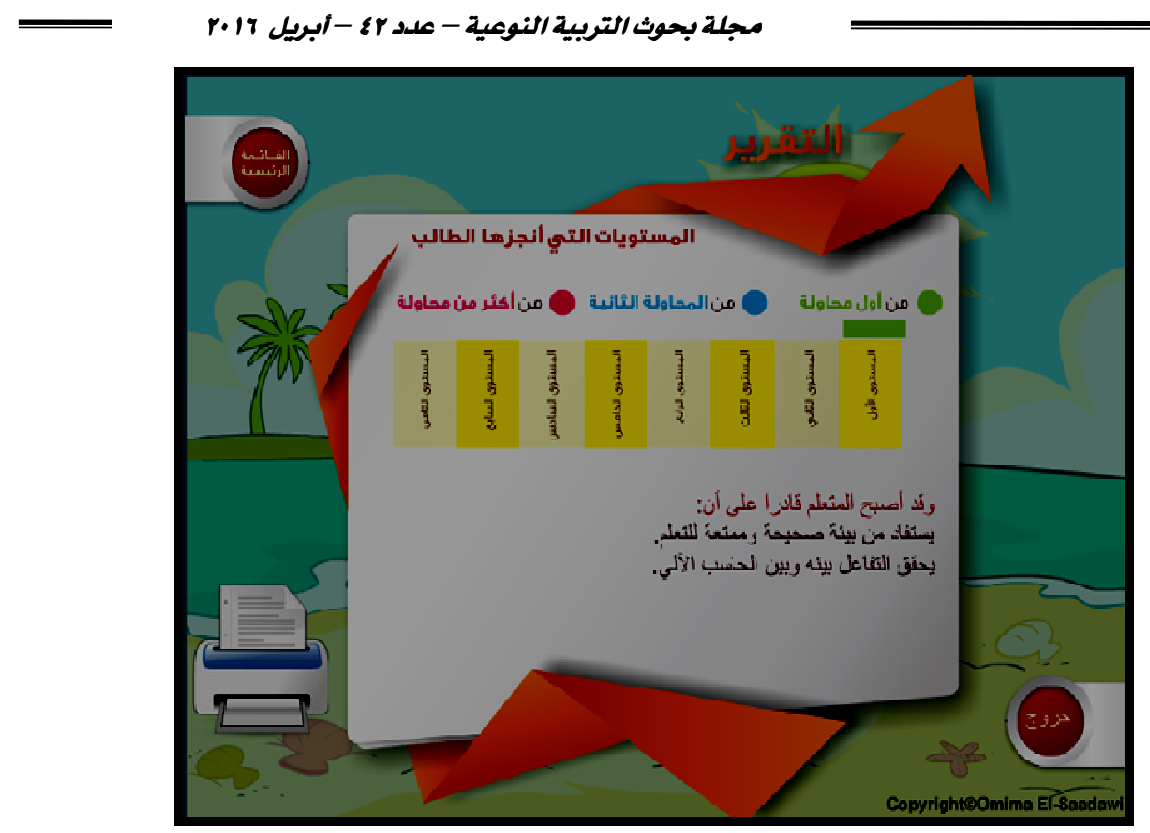

Fig. 5: Print Report ButtonScreenshot

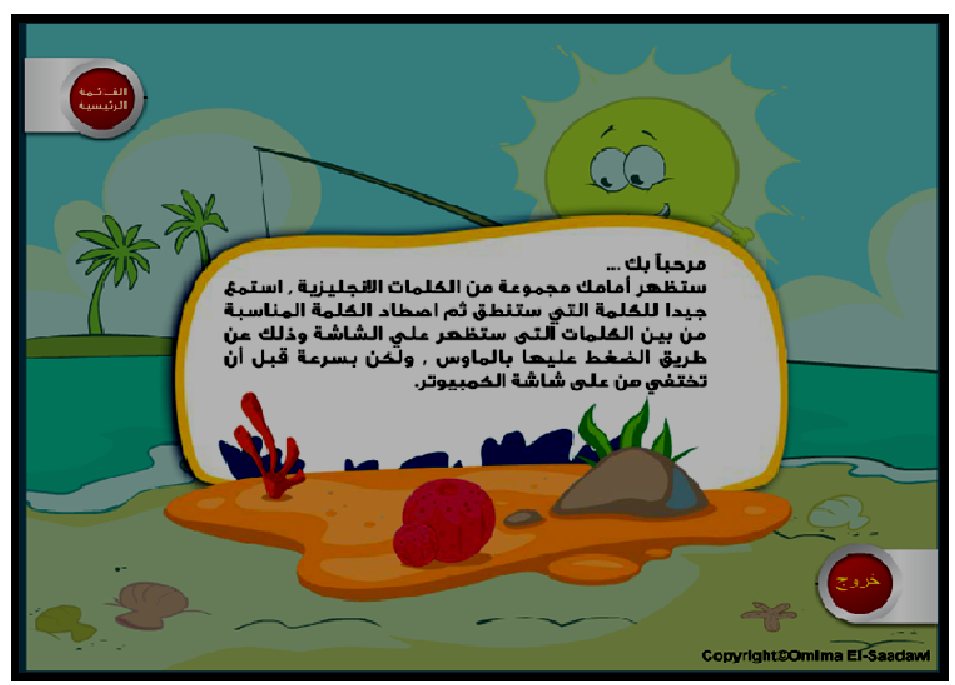

Fig. 6: InstructionsButtonScreenshot 


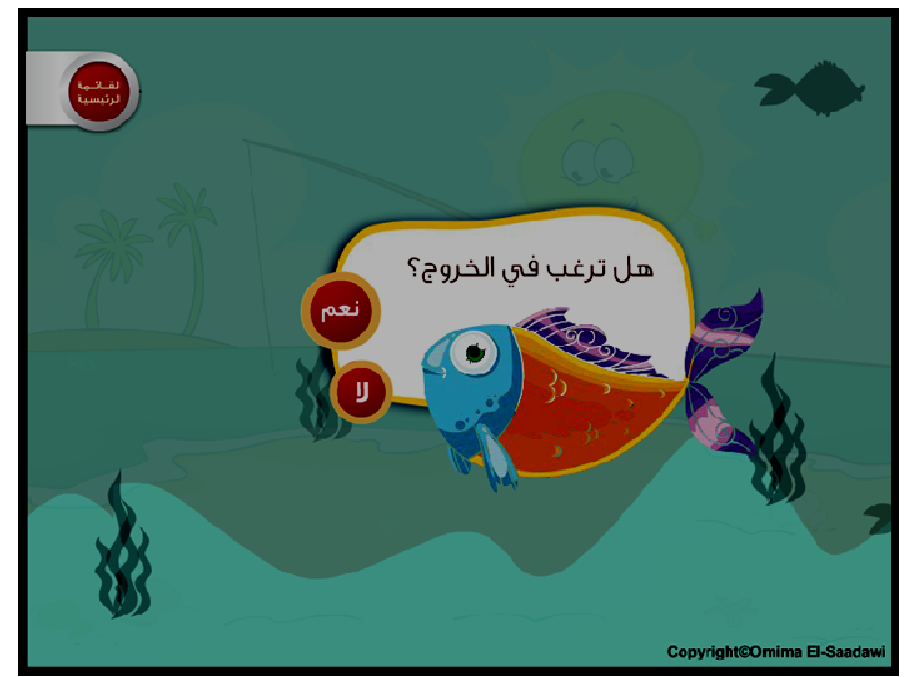

Fig. 7: Exit ButtonScreenshot

\subsection{Assignment of the players}

The aim of the players is to catch the word that he/she listens to it. The player wins the game (passes the level) by catching the right word quickly. The game ends when the pupil ends eight levels. In each level the goal of the player is to catch the correct word, but the difficulty of levels increases gradually

\section{Conclusion:}

This paper presenteda proposed electronic instructional game to improve decision taking skill. The game design is based on a proposed framework. The frameworkreflects the distinctive characteristics of an instructional design/development process for the creation of game-like learning environments.

The proposed framework is applied to design an electronic educational game used to improve decision taking skillfor the sixth primary pupils in Egypt. The proposed game was programmed using Action Script language. This language is one of the most powerful tools for game development.

The game is based on the Egyptian Intended Learning Outputs (ILOs) for primary schools. The objective of the game is to develop the 
decision taking skill and improve the time of taking the right decision in English language curriculum for sixth grade pupils.

To achieve its objective, the game is composed of three main modules; Learning module, Instructional Design module, and Evaluation module. The players can be evaluated as individual players or they can compete as a group under the supervision of a teacher. The teacher can print report about every player. Every player can obtain a feedback on the outcomes of his actions. In a future work we will apply the developed game on a sample of sixth grade pupils to examine its ability on improving decision taking skill.

\section{Reference:}

- Gredler, M. E. (1996). "Educational games and simulations: a technology in search of a (research) paradigm". In D. H. Jonassen (Ed.) Handbook of Research for Educational Communications and Technology (pp. 17.1-17.7). Missouri: Simon and Schuster.

- North Central Regional Education Laboratory [NCREL], \&Metiri Group. (2003). en Guage $21^{\text {st }}$ century skills: Literacy in the digital age.

- Arslan, A. (2006). "The attitude scale toward making computer supported education". Journal of the Faculty of Education. 2/2: 34-43.

- Federation of American Scientists. (2006). "Summit on educational games: Harnessing the power of video games for learning"

Retrieved from:

http://www.fas.org/programs/ltp/policy_and_publications/summit/Summit\%20o n\%20Educational\%20Games.pdf

- Pivec, M. (2006). "Affective and Emotional Aspects of Human-Computer Interaction: Game-Based and Innovative Learning Approaches". IOS Press Publisher

- Gungormus, G. (2007). "The Effect ofGames Used Web Based Education on Success andPermanency". M.A. Thesis. Gaza University, Ankara.

- Wastiau, P., Kearney, C., \& Van den Berghe, W. (2009). "How are digital games used in schools?". European Schoolnet. 
- U.S. Department of Education. (2010, November). "Transforming American education: Learning powered by technology".

Retrieved from: http://www.ed.gov/sites/default/files/netp2010-execsumm.pdf

- Johnson, L., Smith, R., Willis, H., Levine, A., \& Haywood, K. (2011). The 2011 Horizon Report. Austin, Texas: The New Media Consortium.

Retrieved from: http://www.net.educause.edu/ir/library/pdf/HR2011.pdf

- McClarty K. L., Orr A., Frey P. M., Dolan R. P., Vassilev V., McVay A. (2012). "A Literature Review of Gaming in Education". Pearson Available online at:

http://formative.pearsonassessments.com/hai/Images/tmrs/Lit_Review_of_Gami ng_in_Education.pdf

- Hawes Z., McManus J., Naqvi S., Martinussen R., Pelletier J. (2013). Improving children's ability to self-regulate through computerized cognitive training: a randomized controlled study, in Poster Presentation, Biennial Meeting of the Society for Research in Child Development (Seattle) 


\section{الملخص العربي}

إن التعلهم القائم على الألعاب التعليمية على مدى السنوات الماضية يعتبر واحسدا مـن أكثر

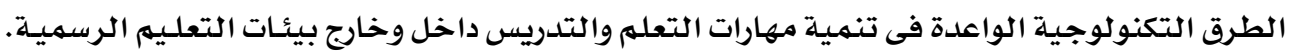

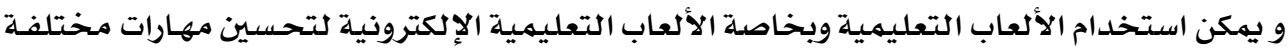

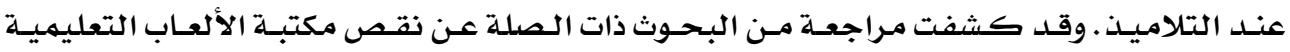

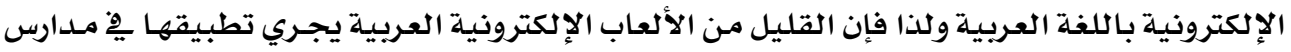

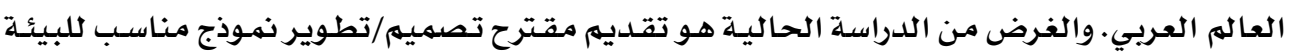

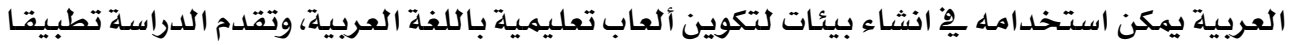

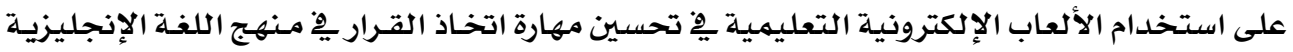
لطلاب الصف السسادس. 